930.85(497.7)

\author{
Ljupcho S. Risteski, (North Macedonia) \\ Institute of Ethnology and anthropology \\ Favulty of Natural Sciences and Mathematics \\ University "Ss.Cyril and Methodius"-Skopje, \\ e-mail: risteski@ukim.edu.mk
}

\title{
MACEDONIAN NORTH BORDER - POLITICS AND REFLECTIONS. ON THE MEMORIAL CENTER OF ANTI-FASCIST ASSEMBLY FOR THE PEOPLE'S LIBERATION OF MACEDONIA (AAPLM) IN PELINCE, THAT MARKS MACEDONIAN RECENT PAST
}

\begin{abstract}
After the independence of the Republic of Macedonia, one of the issues in the sequence of the problematization of Macedonian national identity, of the Macedonian state and Macedonians, internally and by the neighboring states and nations, was the problem of obstruction of the celebration of the jubilees related to the Anti-Fascist Assembly for the People's Liberation of Macedonia (AAPLM) at the Monastery St. Prohor Pcinjski in Serbia settled on the North Macedonian Serbian borderline, now, officially in Serbia. As a result, Macedonia started to consider alternatives for celebrating the anniversaries of AAPLM openly. Thus, in 2004 the construction of the memorial Center of AAPLM in Pelince, a location only a few kilometers away from the Serbian-Macedonian border and few kilometers from the Monastery St. Prohor Pcinjski. However, instead of closing this problematic issue, this Center opened new debates, interpretations, and readings of Macedonian national history and identity.
\end{abstract}

Keywords: Memorial Center dedicated to Anti-Fascist Assembly for the People's Liberation of Macedonia (AAPLM), Macedonian national identity, the 2nd of August 1944, Macedonian state, Macedonia 
One of the most interesting cultural phenomena of our day is the way in which memory and temporality have invaded spaces and media that seemed among the most stable and fixed: cities, monuments, architecture, and sculpture... We have come to read cities and buildings as palimpsests of space, monuments as transformable and transitory, and sculpture as subject to the vicissitudes of time.

- Andreas Huyssen Present Pasts (7)

\section{Introduction}

"...I would like to mention a project whose meaning is much more political, historical, national, than economical or financial. In 2003 we marked, and we are celebrating, the 100 anniversary of the Ilinden uprising of the Macedonian state. I share the estimation and the feeling of many of our citizens that we are not doing it in a true and the most dignified way (...) I want to mention that this, as well as the previous years, we have been through humiliating moments as a nation and as a state while trying to visit the place where the first AAPLM, the Monastery "Prohor Pcinjski."

Next year another great jubilee is taking place, 60 years from the first AAPLM, i.e., creating a modern Macedonian state. What we should never allow is that the dignity of the most important and holiest events of our history depends on the caprices and the moods of priests from another church, the relation of this church and the authorities of this state, or the ties of this church to the Macedonian Orthodox Church.

This is why the Government decided to build a memorial center dedicated to AAPLM. The location has already been chosen; it is near the village of Pelince, at the border with Serbia, only a few kilometers from the monastery of Prohor Pcinjski. The Memorial Center will include a memorial house, a monument, and a park. The project will be selected following an appropriate procedure, a public announcement, opened in the coming two months. The whole project should be realized and solemnly promoted on the $2^{\text {nd }}$ of August 2004, marking the jubilee of 60 years of the AAPLM."

These are the words of the Premiere of the Government of the Republic of Macedonia, Branko Crvenkovski, spoken in front of the Parliament in 2003, announcing the intention of the Government to build a memorial center dedicated to the AAPLM. This decision was made to put an end to the humiliations caused to Macedonians and Macedonia, especially the opprobrium of the state delegations that were attending the celebrations in the years following Macedonian independence, due to the problems caused by the Ser-

1 Speech of the Prime Minister of RM, Mr. Branko Crvenkovski, in front of the members of the Parliament. Stenographic notes from the $41^{\text {st }}$ parliamentary session held on the $5^{\text {th }}$ of November 2003. 
bian Orthodox Church (SOC), that did not allow an official visit to the monastery St. Prohor Pcinjski, where the first AAPLM was held, on the $2^{\text {nd }}$ of August 1944, on the Christian holiday dedicated to St. Ilija.

\section{On the issue of celebrating AAPLM in the monastery of St. Prohor Pcinjski}

After the proclamation of independence of the Republic of Macedonia, one of the issues related to Macedonian national identity, of the Macedonian state and Macedonians, internally and by the neighboring states and nations, was the problem of obstruction of the celebration of the jubilees related to the Anti-Fascist Assembly for the People's Liberation of Macedonia (AAPLM) at the Monastery St. Prohor Pcinjski, which was officially declared that according to the new international border between Macedonia and the rest of Yugoslavia, at the beginning of the nineties, it remained in the part of Serbia. The obstructions and questioning of celebrations at the monastery, where the memorial room dedicated to AAPLM was located, as well as the memorial plaque containing data on AAPLM, started to intensify and became more drastic after the religious objects in Yugoslavia. The Republic of Macedonia was returned to the religious institutions, especially the MOC and the SOC, which conflicted for years. The proclamation of autonomy of MOC happened at a gathering held on the $18^{\text {th }}$ of July 1967, where MOC declared itself an inheritor of the Ohrid Archbishopric, following the example of other churches in the region. This was when the "process of recognition" of MOC started, by SOC and the Patriarchy and other sister churches, that has been going on for around 40 years (Dimevski, 1989:21). Thus, the relations between these two Churches have been highly sensitive during this period. Immediately after returning its property, SOC removed all signs and monuments that glorified the creation of the Macedonian state in 1944 and transferred them to the Museum in Vranje. Even the efforts of the Yugoslav and Serbian Government and other state organs to mediate regarding this problem, aiming to enable Macedonian state delegations to mark the holiday of the Macedonian state, were without success. In 2002 the celebration was held in front of the monastery, at the state-owned land, in front of the water tap, on an improvised stage. SOC then referred to privacy and autonomy concerning property and legal issues and did not let the biggest state holiday of Macedonia be celebrated in the monastery. "The reasons, as they were stated to us today, is that this is private property and that the Serbian state cannot order the church to respect some political decisions."

\section{Ethnography on the latest boundaries demarcations of Macedonia's North Border}

Since the border with Yugoslavia is the only Macedonian border that was initially an internal republican border and was only recognized as an international border following the break-up of the common state, it was, not surprisingly, subject to dispute. The essential disagreement concerned the monastery of Prohor Pcinjski

2 Irina Gelevska, The monks of St. Prohor Pcinjski, heard about the plaque for the first time, reporting for A1 TV news, 19.07.2003. 
, which seemed to be, according to recent evidence, a few hundred meters inside Serbia. The monastery is symbolically vital for Macedonia because essential decisions that led to the formation and constitution of the Macedonian Republic were made there during World War II. Logically, present-day Macedonia is keen to have such a place within its territory, especially given that the borderline is not clear in that area.

To delimit a common border, Yugoslavia and Macedonia established a Joint Boundary Commission in 1996 and tasked it to delimit the borderline and prepare a boundary agreement. The Commission's work was finalized at the 14th meeting held in Skopje on 14-15 February 2001. A border agreement was signed on the 23rd of February by the President of Macedonia, Boris Trajkovski, and the President of Yugoslavia, Vojislav Kostunica. The ceremony was held during the Summit of leaders of Southeast European States. Both presidents emphasized that the Agreement resulted from good relations between the two states and their contribution to regional stability. The Macedonian Parliament ratified the Agreement on the 1st of March 2001. It will enter into force one month after ratification by the Yugoslav Parliament, which was still outstanding at the time of writing. The Agreement between the Republic of Macedonia and the Federal Republic of Yugoslavia on the Definition and Description of the State Border includes a detailed description of the $280 \mathrm{~km}$-long borderline. The borderline is also depicted on a set of topographic maps at 1:25,000 scale. It has been proposed that the borderline should be demarcated following the Agreement.

Concerning the two states' most contentious dispute - that concerning the monastery of Prohor Pcinjski - it is understood that although this site remains on the Yugoslav side of the line, a special agreement will govern its maintenance and allow Macedonians to visit the monastery as well as Yugoslavs to visit specific sites on the Macedonian side of the boundary. On another side, Kosovo Parliament in 2002 got the Resolution of not recognizing the previous Agreement between Macedonia and the Federal Republic of Yugoslavia in the part of Kosovo border, which made even complicated the situation. It meant that Macedonia started a new border demarcation of the Macedonia Kosovo border in 2008, which lasted till 2009 when it finally was signed Agreement between the two countries, which was also problematized as not valid by the Serbian side.

\section{What does monastery St. Prohor Pcinjski represent to Macedonia and the Macedonians?}

As we already mentioned, on the $2^{\text {nd }}$ of August 1944, on the Christian holiday of St. Ilija, the first AAPLM was held in the monastery St. Prohor Pcinjski. This was the moment when contemporary Macedonian state was formed when the Macedonian nation was officially declared, and Macedonian language was proclaimed, for the first time, as an official, and has been put in official use in the People's Federative Macedonia, which became a constitutive part of the Yugoslav Socialistic Federation. The monastery St. Prohor Pcinjski presents one of the essential rhetorical toposes of Macedonian national history, but also of the political history that is learned by our citizens, about our history, our cultural heritage, in a way that the topos itself and the landscape that surrounds it becomes closely related to power and memory. 
The concept of social memory is connected to the development of emotional and ideological ties with specific histories and geographies. In the monastery St. Prohor Pcinjski, Macedonian post-war collective memories are filled with emotional and ideological feelings. This placemark the creation of the modern Macedonian state; it also symbolizes the problematization of the contemporary Macedonian history between the Yugoslav federalist and Macedonian autonomist ideology. This is when the problematization of ideas on the ethnic distribution, i.e., "ethnic boundaries" of Macedonia, began and the abandonment of ideas for the eventual unification of Macedonian ethnic territories of that time. An article published in the newspaper "Ilinden Path" in 1944 signed by Metodija Andonov - Chento, but probably written by a number of members of the Initiative Committee for organizing o AAPLM, inviting delegates from three parts of Macedonia states, the following: "...the first Macedonian People's Assembly will symbolize the will of the whole Macedonian people to be complete, free and united..." (ASNOM, T.1, Kn.2, 1984: 79-90). Many people in Macedonia have wondered for decades what were the motives of the authorities of that time to organize the official declaration of contemporary Macedonian state precisely in the monastery of St. Prohor Pcinjski. From today's perspective, analyzing the available archive documents on the organization of AAPLM, it is visible that the most essential motive was that this should happen on a liberated territory, which at that time included the Kumanovo region, i.e. the area of Kozjak. The fact that the delegate did not know where to go for the Assembly is evident from a letter from May 1944 written by Vera Ciriviri - Trena, sent to Ljupco Arsov, that mentions a letter that they received, stating: "...you should immediately sent people to our liberated territory, that covers the road from Kum(anovo)-Kr(iva) Pal(anka) and Kum(anovo) Vra(nje), including the whole right bank of Juzna Morava river" - which was not completely clear for them, so they asked for more detailed explanation: "But this is not sufficient, people asked where and how they should come. If you could please send some information.." (ASNOM, T.1, Kn.2, 1984: 92-93).

Still, the archive document contains information that some of the participants of AAPLM, when mentioning the place where the Assembly was held, emphasized the historical importance of the monastery St. Prohor Pcinjski.

Citizens also wondered how it came about that the monastery St. Prohor Pcinjski was included or given to the Serbian state since, in Macedonian national memories, this monastery is a Macedonian one, located in Macedonian ethnic territory. As far as it is publicly known, official Macedonian historiography has no documents explaining when, how, and in which manner the final territorial determination of the monastery, i.e., From this moment, it started to belong to one of the socialistic republics, occurred. Here one should take into account the fact that there were no previously established borders of Macedonia. Still, having in mind the activities related to previous divisions of Macedonia, it is clear that they were precisely known. Immediately after the formation of the Federal People's Republic of Yugoslavia, to the concrete demarcation of the Republic's federal borders, the first territorial disputes and problems appear (ASNOM vo sozdavanjeto..., 1987: 219-231), especially about the border areas precisely in the area of Kozjak where the monastery is located. Thus, at the Second AAPLM, held 28-30 December 1944, after the issue of the administrative and territorial division and the solution of administrative and economic problems of the local population has been posed, Svetozar Vukmanovic-Tempo 
took the floor and, according to his words, without being politicized, stated: "...Macedonian and Serbian partisans are quarreling around a damn village of Kozjak, whose is this village, Macedonian or Serbian....What is the result? It is obvious that the enemy entered our lines and started digging. At the same time, our goal is to clearly state that Macedonia is Macedonian and Yugoslavian, that Serbia is Serbian and Yugoslavian. And that village, Kozjak, this village belongs to Tito's Yugoslavia, no matter if it is in Macedonia or Serbia.." (ASNOM, T.1, Kn.2 1984: 455). The same rhetoric in the spirit of brotherhood and unity on one side, but blurring and pushing aside the problems, on the other hand, was used by Dimitar Vlahov, who in the spirit of defining the borders and the emergence of local-patriotism has clearly expressed Macedonian fears of such imprecision that could reflect upon collective memories of certain unclear and insecure events. Macedonians "know what it means to define borders between one area and another. And we know what borders are these. In 1913 a border was put between Yugoslavia and Greece, between Yugoslavia and Bulgaria and between Bulgaria and Greece, when Macedonia was divided into three parts...” (ASNOM, T.1, Kn.2 1984: 455).

Thus, after more than 40 years, the statements of D. Vlahov have come to pass. This problem still exists in Macedonian collective memory, while due to the formality of the inter-republic borders, the problem was neither opened nor closed. Still, the ambivalent feelings related to this monastery and AAPLM were more than visible in Macedonian national official and unofficial rhetoric during the whole time. After the final demarcation of international borders between Yugoslavia and Macedonia, the monastery remains in the boundaries of Serbia.

\section{The building of the Memorial Center of AAPLM in Pelince}

The management of memories related to specific locations and collective remembering provides a place and a space for the realization of the rituals or ceremonies that have a collective character and, sometimes, eternal memory. As emphasized by Nora P. (Nora P., 1989: 7-25), the monuments become locations of memory. Such sites become markers or borderlines of the remembered geography and history, establishing a connection between official and local cultures. Thus, the collective public memory becomes "a dynamic process through which groups map the myths (in the anthropological sense of the word) about them and their world through specific time and place (Till 1999: 254). The mapping process is a part of the project that creates individual and group identities, symbolically coded through public monuments.

As a result, at the beginning of the $21^{\text {st }}$ century, due to the impoverished relations between MOC and SOC, people started thinking about alternatives for celebrating AAPLM anniversaries in Macedonia. Despite the efforts from the Macedonian side, mainly of MOC, for initiating a process for re-examining the property and legal issues and returning the monastery to Macedonian territory, and thus putting it under the authority of MOC, there were parallel processes that have practically marked the process of 'deterritorialization' of one of the most important symbols of the Macedonian state. Immediately after the public was informed on finding alternative solutions for celebrating AAPLM, some discussions disputed such efforts. Firstly, they were countered by VMRO- 
DPMNE, the opposition party at that time, against the creation of alternative monuments that would mean giving up the monastery Prohor Pcinjski, one of the most critical signs of Macedonian statehood. In public, on electronic forums, there were discussions on 'surrogate solutions.' ${ }^{3}$ On the other hand, the Government thought that the construction of such a monument would be a solution to the problem.

This process started in the year 2000 when, following an initiative of MOC, construction began on a monastery dedicated to St. Prohor Pcinjski in the village of Strezovce in the Kumanovo region. However, up to that moment, there was no church dedicated to St. Prohor Pcinjski in the village. And in it, following a proposal of the metropolitan Gorazd and Kiril, a memorial room of AAPLM should be built.

On the other hand, the Government of the leftist SDSM, that was an openly prosecular state, distancing themselves from these activities of the Church in RM, in 2003, after a hastened procedure has authorized the Ministry of culture to implement a policy on constructing a memorial center of AAPLM near the village of Pelince.

At the beginning of 2004, the Ministry of Culture of RM announced a public competition for architectural projects for the memorial Center in Pelince. The Architectural Association immediately reacted, stating that "there is not sufficient time for preparations, the commission has not been announced, and the public call is not respecting copyright." Still, the Ministry of Culture of RM accepted, following a quick procedure, the proposal of architect Georgi Konstantinovski for the Memorial Center of AAPLM, and the Commission consisted of: "Boro Mitrikevski - sculptor, Dragan Stojanovski - architect, Bojan Ivanov - art historian, Risto Tanevski - art historian and advisor on the protection of cultural heritage in the Ministry of Culture and Biljana Tanovska - lawyer in the same Ministry."

Explaining the decision with time shortage and the fact that the celebration of the $60^{\text {th }}$ anniversary of AAPLM should be organized in a dignified way, the Government of RM made a decision that was announced through the media, that through a direct agree-

3 Pelince as a surrogate location of st. Prohor Pcinjski, Forum discussion Zazabava.com.

4 Irina Gelevska, In the village of Strezovce near Kumanovo, a monastery is built A1 news, 23.08.2003, A1.com.mk. "There is a church of St. Nikola in the old village, and three years ago in the new village, at a place known as 'the cross' a 30m cross was built in honor of 2000 years of the birth of Jesus when the foundation of the new monastery was put, "St. Prohor Pcinjski," that is located at $25 \mathrm{~km}$ air distance from the monastery with the same name at Serbian territory.

"The monastery St. Prohor Pcinjski in the village of Strezovce started to be built on the $10^{\text {th }}$ of October $2000(. .$.$) The chosen place for it was Ilinec, where there is a spring of St. Ilija. The$ construction firm Kozjak from Kumanovo has built the monastery's exterior, and a water reservoir was built for the village and the monastery." Irina Gelevska, A monastery is built in the village of Strezovce near Kumanovo, A1 TV news, 23.08.2003, A1.com.mk.

5 Museums of AAPLM will grow like mushrooms; two memorial Centers of AAPLM will divide the citizens of Ilinden, Dnevnik, n. 2299, Saturday, the $18^{\text {th }}$ of March 2006. Menche Atanasova Tochi, "New Prohor Pcinjski at Macedonian territory, A1 news, 27.09.2003, A1.com.mk.

6 The announcement for the Memorial Centre of AAPLM is not legal, Vest, Year: 4, issue number 1116, Tuesday 23/3/2004.

7 Architect Kostandinouski got the Memorial Centre of AAPLM, Vest, Year: 4, issue number 116, Tuesday, 23/3/2004. 
ment, the construction would be done by the "Beton" company. At the same time, the mosaic will be created by the well-known Macedonian artist and Professor at the faculty of arts in Skopje, Rubens Korubin.

Thus, the primary issue for which the whole project was questioned is the accusations of not respecting the legal regulation regarding projects of public interest in RM and the lack of transparency in the work of the Ministry of Culture while making the most important decisions related to this issue. While anthropologist Keith Brown (Brown K., 2003: 153-180), in his book dedicated to contemporary Macedonia and the problematization of the Macedonian nation, had an opportunity to investigate the documentation related to the construction of one of the giant monuments in RM, dedicated to the Ilinden uprising, created by Jordan and Lira Grabul in Krushevo, that is kept in the Archive of Macedonia, the author of this article did not have such opportunity, since even after several efforts to look into the materials that refer to the construction of this monument he failed in doing that, due to the information given by the Ministry of Culture of RM that such materials do not exist at the Ministry, but that they should be found in the Government of RM, which is, of course, a long process. The avoidance to open the complete documentation related to the Center could be also interpreted as a continuation of the fierce political intrigue between SDSM and VMRO-DPMNE, aiming to prove the lack of transparency, which is finally harmful only for the Macedonian cause.

Thus, after the change of Government in 2006, the new one has immediately asked for a revision of the financial arrangements of the Ministry of Culture of RM. It resulted in a public report of the state supervisor, which states that the Ministry undertook general purchases without a previously granted agreement from the Ministry of Finances, which resulted in "non-transparent selection of the best contractor."

"Following the conclusions of the Government, the Minister has issued a document saying that the procurement should be done through a negotiating procedure, without a previously obtained agreement from the Ministry of Finances - Sector for public procurement. The procurement based upon selecting the best candidate was done with the "Beton" construction company from Skopje. The Agreement for construction valued at 120.000 denars was signed on the same day, which resulted in a non-transparent selection of the best contractor. ${ }^{11}$

8 Two million euros were spent on the Memorial Centre of AAPLM without a public bid, Vreme, issue number 106, 08.06.2004.

9 The written, electronic message of the author of the article to the Speaker of the Ministry of Culture, Mr. Aleksandar Gjorgjevski, and oral reply.

10 Telephone conversation of the author with a person employed at the Ministry of Culture, directly connected at that time to the activities for the realization of the project of the Memorial Center.

11 Final report of the authorized state supervisor on the Ministry of Culture of RM, 2005, number 1103-455/6, from 03.10.2006. 


\section{One is 'ours,' the other is 'yours'}

There should not be two Macedonias, one 'ours' and the other 'yours.' the words of the President of RM, Branko Crvenkovski, said in 2007 in front of the Macedonian public, alluding to the continuous divisions o the two biggest political blocks in the Macedonian arena, SDSM, and VMRO-DPMNE, for the good of Macedonia. Unfortunately, this celebration that aimed towards "facing history with a view towards the future" obviously lacked resonance in the political circles of the fierce enemies, and the bitter truth of the constant divisions of the Macedonian public remained vivid in the ears and souls of the citizens of Macedonia.

For decades the celebration of the biggest national holiday, the $2^{\text {nd }}$ of August, instead of being a symbolic topos and tempus of the Macedonian national idea, became an event when this idea is being questioned, following the dynamics of the interior political events in the country. Depending on the orientation of the ruling parties, the content and form of the celebration of all holidays changed, i.e., depending on the leftist or right orientation of the parties, which in our circumstances is interpreted chiefly through a number of variants. Still, the leftists are usually identified as more progressive, social-democratic while the others are identified as conservative, patriotic, and nationalistic. In the case of Ilinden, the right-oriented parties usually decide to favor Ilinden of 1903, while the others do prefer Ilinden of 1944 - this is how these holidays became a basis for political separations re-readings and interpretation of the recent and past history of Macedonian people. Thus, instead of being a place where politicians would meet and national unity would be shown, the memorial centers and monuments became places for disputes and conflicts. A quick overview of the media reports in RM could prove the previous statement: "Crvenkovski in Krushevo, Gruevski in Trnovo," the Chief of the state Branko Crvenkovski and the future Prime Minister of the new Government Nikola Gruevski will not meet at the central celebration of Ilinden at Mechkin Kamen in Krushevo, reports Dnevnik daily from August 2006. "Gruevski will most probably appear at the gathering of the Macedonians from Aegean Macedonia in the village of Trnovo near Bitola," states the same source.

Such events initiate reactions of Macedonian citizens: "It's no good that they are separating, this is our holiday, we were fighting for freedom, and now we are doing the same. It's better than all of us are at the same place, if we are all together", citizens say.

$12 \quad$ Crvenkovski on Pelince: Ilinden is a day for facing history with the view towards the future of Macedonia, TV Channel 5, 02.08.2007.

13 Branko Gorgevsi, Pelince is built from Ilinden to Ilinden, taken from Dnevnik, Wednesday, the 26th of July 2006, blog Staro Nagorichane.

14 Goran Momirovski, Gruevski: Ilinden is a holiday of the Macedonian striving, 2.8.2007, A1 TV, A1.com.mk 
EthnoAnthropoZoom

\section{In Pelince, Macedonia is presented through an image made of stone.}

At the memorial Center of AAPLM, where there is a replica of the room where the first AAPLM was held, the main attraction is the monument, a mosaic made on $140 \mathrm{~m} 2$, at the main wall of the building, created by Macedonian painter Rubens Korubin.

Unfortunately, until now, everyone talked about Pelince only in the spirit of questioning the new object, and the Macedonian public, mainly due to the media influences, is presented with images reflecting the unsuitability of the monument in Pelince. It is almost unbelievable, but the Macedonian public received minimal data about the essential and content-wise features of the memorial. Due to the bombardment with information on the problems surrounding the realization of the project, there was a lack of crucial information that should have explained the content of the mosaic, the meaning, and the symbolism of the mosaic text. The mosaic called "Macedonian" remains a mystery for the Macedonian public since no one, media included, has either officially or unofficially read or interpreted the images of Macedonia presented in stone. Up till now, there was only one article in "Tea Moderna." $\mathrm{A}$ journal that is far from influential in creating Macedonian public opinion presents an interview with the artist to discover his thoughts, intentions, and interpretation of the mosaic... There is a lot to say and interpret when the mosaic is in question. Thus, even though the author of this article primarily did not have the intention to talk to the artist R. Korubin, he asked him for a short conversation which would refer to the ideas, realization, and most importantly, his personal story that, through sharing it with the Macedonian public, should become a collective one. The presentation of the collective image of Macedonia is seen by the author Korubin as a personal, individual history of chosen notions and elements that are present in our setting but that are also kept in his memory. "I made a parallel with human life, the birth, which is presented as a sunrise, through the evolution that takes place through life - you grow, you get educated, and finally, human life ends, but we always have new generations and new generations of followers..eternity" (Interview with R. Korubin). Thus, this mosaic can also be read as an interpretation of Macedonia both individually and collectively. Personal experience and interpretation of the most important aspects of the artist's life, according to his own opinion, are related to his early childhood, when he was more related to the female part of the family, his mother, aunts, and grandmothers, who as oral transmitters of family tradition, of "all stories on past generations, have transferred to him this images, that he now uses in his artworks. The artist's individual experience includes certain archetype notions on the homeland, the past, the traditional, and its transmission to the next generations. The images of Macedonia between dream and reality or Macedonian through time and space are reflected, at a conscience or

15 Macedonia through an image made of stone, Kolevska Gordana, Tea Moderna, Weekly magazine for smart and modern, n. 423, year IX, Wednesday, the $29^{\text {th }}$ of October 2008, 18-21.

16 Interview with Rubens Korubin, recorded February 2009. Recorded by Ljupco S. Risteski. 
subconscious level, through an image structure at three levels, which can be interpreted as a reminiscence of the mythological notions of the world, consisting of three parts.

The beginning for the author and Macedonia as well is presented through the morning, i.e., the sunrise at the left side, which bathes in the violet poppies, and then through a subtle switch consisting of folklore elements of Macedonian costumes and their color embroideries, it melts into a bouquet of butterflies, an aspect of the mosaic titled "The Dance of the Butterflies." The image of Macedonia includes elements of the flora and fauna that remained in the memory of the author. Moving towards the right, we arrive at the "Gate of Literacy." This image again contains personal and collective notions and knowledge of the artist, interpreting it through the gate of their family house in Prilep, which offers the spectators different perspectives when being closed and opened.

The slightly opened door is decorated with different letters that reflect the historical development of literacy in Macedonia as one of the 'civilization steps' which bring Macedonia into a new period. At the bottom of the gate, there are different animals characteristic of Macedonia, and from this point on, there is one of the central figures of the mosaic. It is a female figure, with an apron, one of the essential elements of the female, but also of the male costume in the folk tradition of Macedonia, filled with the most significant symbolic connotation related to power, especially the reproductive ability. This female personage is created through a modern artistic transcription. According to the author's interpretation, the mythological Great Mother symbolizes the woman that gives birth to all of us and provides the new generations. In this image, everyone can see one's mother; everyone can see Macedonia as our mother. Presented as holding mythological creatures, i.e., dragons in her hands, holding their heads or tails, it symbolizes victory over evil. The central part of the mosaic is, in fact, the entrance to the Memorial Center. There are a few geometric mosaic forms around the entrance, the circle, and the square that repeat the well-known symbol of the ring and the square, made in golden mosaic stone, which also symbolizes eternity. The circle marks the "eternal movement, and the square means a selected moment when something is constituted when something is done. This is why it presents the cohesion of the two. Thus, the eternal movement contains this selected moment when something is constituted, when something is done" (Interview with R. Korubin)

The middle level or belt contains an artistic transcription of migrations through time; there are images of hunting tribes moving towards a better place, presented with an exceptional dynamic of the horse silhouette, a mythological horse that brings us to a new civilization moment essential for us and Macedonia. A segment of this mosaic is called a tsar element and the other Byzantine element. "They are given through these personages that are associated to this period of civilization, the influence of Byzant" (Interview with R. Korubin). Then there are elements of folk culture, the rural element, containing elements of pre-Christianity. Here the author points towards the symbiosis of the Christian and non-Christian "pagan' elements, as he calls them. All of them again lead to a door. The highest level presents a mountain chain and its reflection in the water, a landscape that turns into the letter M - "as in Macedonia" (Interview with R. Korubin). The upper part also presents the cosmos, with many folklore motifs whose essence is the celestial energy. Then there are the symbols of the moon and the sun - "The night an- 
nounces the day, after the day has passed their insight, and thus there is an eternal continuity" (Interview with R. Korubin)

All three parts of mosaic presentations end up in the golden forest, which, according to the author, is a kind of nirvana. "It presents eternity, the highest moment that says that everything that will be created will last, and will have its projection, of its life energy, forever" (Interview with R. Korubin)

Thus, Korubin experiences this mosaic as his autobiographical portrait, on the one hand, but on the other hand not as a text or a story, although he refers to them several times, "reading them" or "telling them," but as music, "as a melody that presents Macedonia, between dream and reality, or Macedonia through time and space' (Interview with R. Korubin). This music called Macedonia is not disrupted by "any historical personage, there is no Alexandar the Great, no Goce Delchev, no Lazo Kolishevski..” (Interview with R. Korubin)

Starting from the attitudes of Anderson in Imagined Communities (Anderson, 1998) and Homi Bhabha in Nation and Narration (Bhaba H., 1990), one can state that the narratives written by the monuments are in a complex way related to identity and memories and that those monuments participate in the writing of national narratives, feeding cultural identities and memories of the citizens (Rosentals, 2007: 13-14). National monuments are national practice since they produce but often question the meanings of the nation. Still, through their creation, national monuments and other forms of national practices participate in the creation of a "nation" (Shein Avital, 38). 


\section{References}

Андерсон, Бенедикт. 1998. Замислени заеgници. Скопје: Култура.

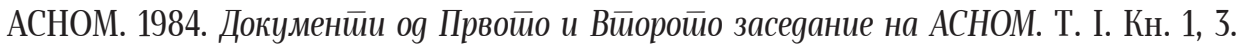
Скопје: Архив на Македонија.

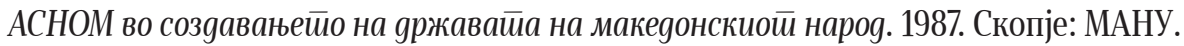

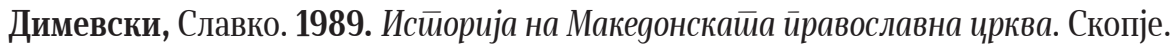

Bhabha, Homi K. ed. 1990. Nation and Narration. London, New York: Routledge.

Brown, Keith. 2003. The Past in Question: Modern Macedonia and the Uncertainties of Nation. Princeton, Oxford: Princeton University Press.

Huyssen, Andreas. 2003. Present Pasts: Urban Palimpsests and the Politics of Memory. Stanford: Stanford UP.

Johnson, Nuala C. 2002. „Mapping monuments: The shaping of the public space and cultural identities“. Visual Communication. Vol. 1 (3), 293-298.

Nora, Pierre. 1989. „Between Memory and History: Les Lieux de Mémoire“. Representations $26,7-25$.

Risteski, Ljupco S. 2010. „Esay On Festivities: Transformation Of The Holiday Calendar In The Republic Of Macedonia From 1991 Until The Present". EthnoAnthropoZoom 8, 63-98.

Rozentals, Darien Jane. 2008. Monumental Amnesia: Reading the Spatial Narratives Written by Contemporary Urban Landscapes. PhD thesis (ракопис). University of New South Wales.

Shein, Avital. 2007. Monuments As a National Practice: The Dilemmas Of Liberal Nationalism. PhD thesis (ракопис). University of Maryland.

Till, Karen E. 1999. „Staging the Past: Landscape Designs, Cultural Identity and Erinnerungspolitik at Berlin's Neue Wache“. Ecumene 6, 251-283.Till, K. (1999) 'Staging the Past: Landscape Designs, Cultural Identity and Erinnerungspolitik at Berlin's Neue 


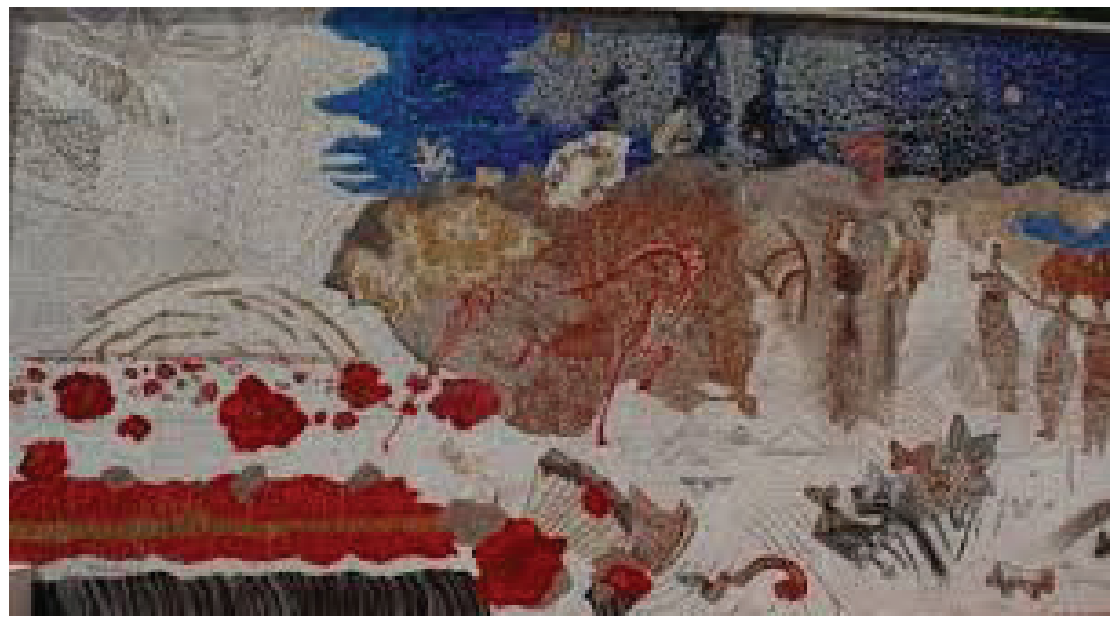

The "Macedonia" mosaic in the ASNOM Memorial Center by the author Rubens Korubin

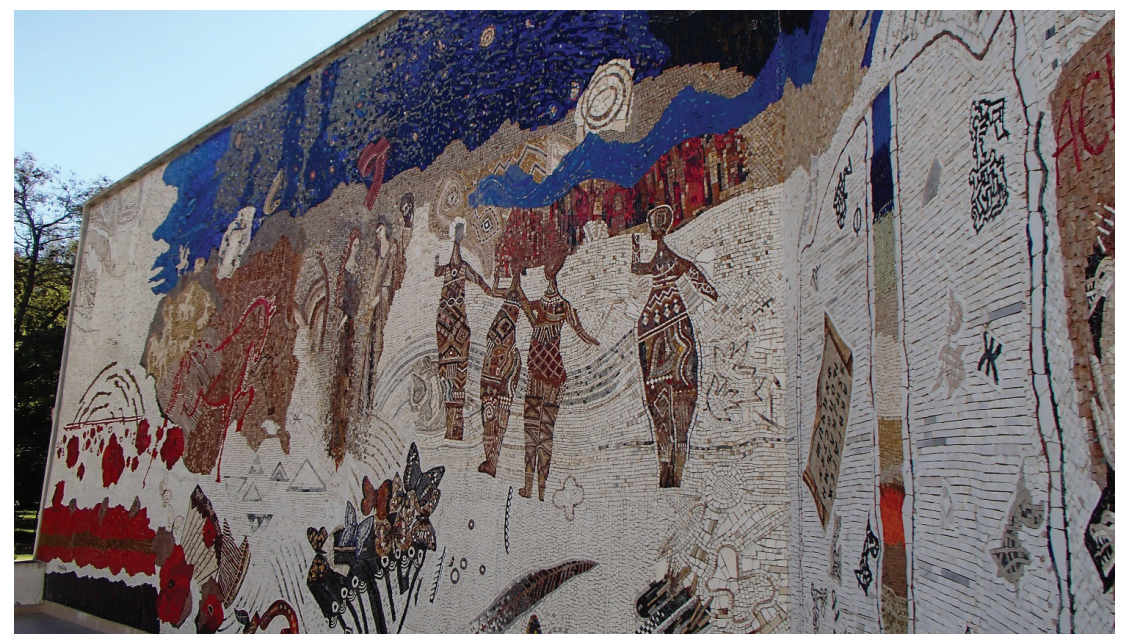

The "Macedonia" mosaic in the ASNOM Memorial Center by the author Rubens Korubin 